\title{
Evaluating wastewater treatment efficiency of two field scale subsurface flow constructed wetlands
}

\author{
A. S. Tilak*, S. P. Wani, M. D. Patil and A. Datta \\ International Crops Research Institute for the Semi-Arid Tropics, Patancheru 502 324, India
}

Constructed wetlands (CWs) are human-made systems designed to treat a variety of industrial, domestic and agricultural wastewaters. We study here the efficiency of domestic wastewater treatment by two field scale subsurface flow CWs under different hydraulic loading rates (HLRs). Each $\mathrm{CW}$ had inlet and outlet chamber for wastewater collection with Pistia stratiotes (water lettuce), two treatment sections consisting of sand and gravel media and four plant species Typha latifolia (Broadleaf cattail) and Cymbopogon citratus (lemon grass - first CW) and (Pennisetum purpureum schum and Pennisetum americanum L (Hybrid napier) and Urochloa mutica (Paragrass-second CW). The wastewater source was from a residential urban colony. The HLRs for the first and second $\mathrm{CW}$ for a three-month period averaged $4.45 \mathrm{~cm} / \mathrm{day}$ and $5.77 \mathrm{~cm} /$ day respectively. The $\mathrm{CW}$ was monitored for quality of wastewater inflows and outflows and nutrient accumulation in plants and sand media. Results showed that the chemical oxygen demand (COD), total suspended solids (TSS), total nitrogen and total phosphate removals in the first and second $\mathrm{CW}$ over a three-month period averaged $42 \%, 74 \%, 39 \%$ and $41 \%$ and $34 \%, 82 \%, 14 \%$ and $35 \%$ respectively. Both the CWs showed similar rates of TSS removal irrespective of the type of wetland plant species. Over the three-month period, average COD, total nitrogen and the phosphate removals were greater in the first $\mathrm{CW}$ compared to the second $\mathrm{CW}$. These results confirm the efficacy of field scale subsurface flow CWs to improve the quality of domestic wastewater in rural communities of developing countries like India.

Keywords: Constructed wetlands, domestic wastewater, field scale, subsurface flow.

\section{Introduction}

CONSTRUCTED wetlands (CWs) are human-made systems that mimic the functions of a natural wetland and have been primarily used to treat domestic and municipal wastewaters ${ }^{1}$. They have also been used to treat different sources of wastewaters such as industrial, agricultural runoff, landfill leachate as well as urban and highway

*For correspondence. (e-mail: a.tilak@cgiar.org) runoff $^{2}$. For the past four decades, CWs have been increasingly used as sustainable treatment systems compared to the conventional treatments (wastewatertreatment plants) due to its low operation and maintenance $\operatorname{costs}^{3}$. The CWs do not require any large and complex mechanical equipment compared to the conventional wastewater-treatment plants which are associated with high energy inputs. As CWs do not require high energy inputs, they can be designed for small/medium rural communities and peri-urban areas for single households and residential blocks. There are two major types of CWs namely subsurface flow and free water surface (FWS), each having different modes of operation, advantages and disadvantages. The subsurface flow CWs have wastewater flowing through the gravel and coarse sand media (no wastewater ponding above the coarse sand surface). The sand media in subsurface flow CWs are required for growth of wetland plants such as Typha latifolia, paragrass and lemon grass. In FWS CWs a water column is maintained for growth of wetland plants such as water hyacinth and Pistia stratiotes ${ }^{4}$. The subsurface flow CWs consist of four main components - wastewater, sandy media, microbes and vegetation which facilitate the excessive removal of nitrogen, phosphorus and heavy metals such as lead, cadmium, chromium and zinc ${ }^{5}$. These four main components operate simultaneously to remove contaminants by physical, chemical and biological processes ${ }^{6}$. The plants in CWs play a major role by causing settling of suspended particulate matter, primary cause for reduction in biochemical oxygen demand (BOD). Another important function of plants is the uptake and storage of contaminants in their above and below ground biomass ${ }^{7}$. However, if wetland plants are not regularly harvested, they return the nutrients to the sandy media through senescence of its leaves, stems and roots. Also besides the nutrient uptake and storage, plant roots provide a large surface area for increasing microbial growth activities ${ }^{8}$. Klomjek and Nitisoravut ${ }^{9}$ quantified the effect of using eight plant species in a $\mathrm{CW}$ for improving wastewater quality. They reported that cattail (Typha angustifolia) had better nitrogen assimilation potential and the Asia crabgrass was most efficient for $\mathrm{BOD}_{5}$ removal (the amount of the dissolved oxygen required by aerobic microbes to breakdown the organic 
matter at $20^{\circ} \mathrm{C}$ for 5 days is known as $\mathrm{BOD}_{5}$ ). This $\mathrm{CW}$ with 8 plant species removed $72-78.9 \%, 43-56 \%, 67-$ $76.5 \%$ and $28-44.9 \% \mathrm{BOD}_{5}$, suspended solids, $\mathrm{NH}_{3}-\mathrm{N}$ and total phosphorus respectively. Most of the subsurface CW studies in the literature have been pilot scale or laboratory scale with very few demonstrating field scale approach.

The present study focuses on field scale demonstration of subsurface flow CWs having a unique combination of wetland plant species such as water lettuce, cattail, lemon grass, hybrid napier and paragrass. The specific objectives of this three-month (January-March 2015) field scale study were to: (i) quantify the effect of having different hydraulic loading rates (HLRs) and hydraulic retention time (HRT) each month for comparing the treatment efficiencies of two subsurface flow CWs; (ii) determine the nitrogen and phosphorus accumulation in wetland sand media for two subsurface flow CWs; (iii) quantify the nitrogen and phosphorus uptake of 5 wetland plant species and (iv) determine the effective species for nitrogen and phosphorus removal.

\section{Materials and methods}

\section{Site location}

The two field scale subsurface CWs are located on the campus of the International Crops Research Institute for the Semi-Arid Tropics (ICRISAT), Patancheru, India. These two CWs received domestic wastewater from an urban residential colony nearby ICRISAT campus. Both the $\mathrm{CWs}$ received the same inlet wastewater during the three-month period.

\section{Field scale $C W S$}

The domestic wastewater from an urban residential colony is transported into a settling tank (60-70 $\mathrm{m}^{3}$ capacity) using a Kirloskar diesel pump. The treatment capacity of each $\mathrm{CW}$ is $5 \mathrm{~m}^{3} /$ day depending upon the retention time (3-5 days). Both the CWs are divided into four chambers, A to D (Figure 1). The chambers not only serve as a wastewater inlet and outlet collection unit but they also maintain the hydraulic head. The treatment chambers (B and $\mathrm{C}$ ) in both CWs have coarse sand (3-5 mm diameter) and gravel media (40 $\mathrm{mm}, 20 \mathrm{~mm}$ and $10 \mathrm{~mm}$ size). The dimensions of treatment chambers $\mathrm{B}$ and $\mathrm{C}$ in each $\mathrm{CW}$ are shown in Figures 1 and 2. The thickness of filter media (sand + gravel) layer in both CWs is $1 \mathrm{~m}$. The individual depths of three gravel sizes $(40 \mathrm{~mm}, 20 \mathrm{~mm}$ and $10 \mathrm{~mm}$ ) and the sand media were $25 \mathrm{~cm}$ respectively. In chambers B and C, the $40 \mathrm{~mm}$ gravel was kept at the bottom, followed by $20 \mathrm{~mm}$ and $10 \mathrm{~mm}$ gravels. The sand media was placed on top of the $10 \mathrm{~mm}$ gravels in both the CWs (Figure 1). All the five wetland plant species were obtained from the ICRISAT campus. The paragrass was established in the second CW on 17 February 2015. The schematic view of the first and second $\mathrm{CW}$ is shown in Figures 3 and 4 respectively.

\section{Inlet and outlet flow monitoring}

The influent and effluent flow rates were measured daily using mechanical Itron flow meters (Figure $5 a$ ). The

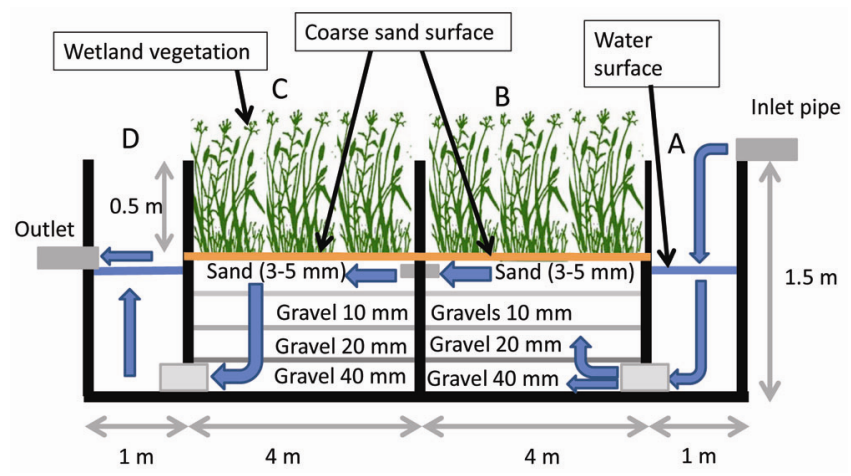

Figure 1. Cross-section of first and second subsurface flow CWs consisting of four treatment chambers (A to D).

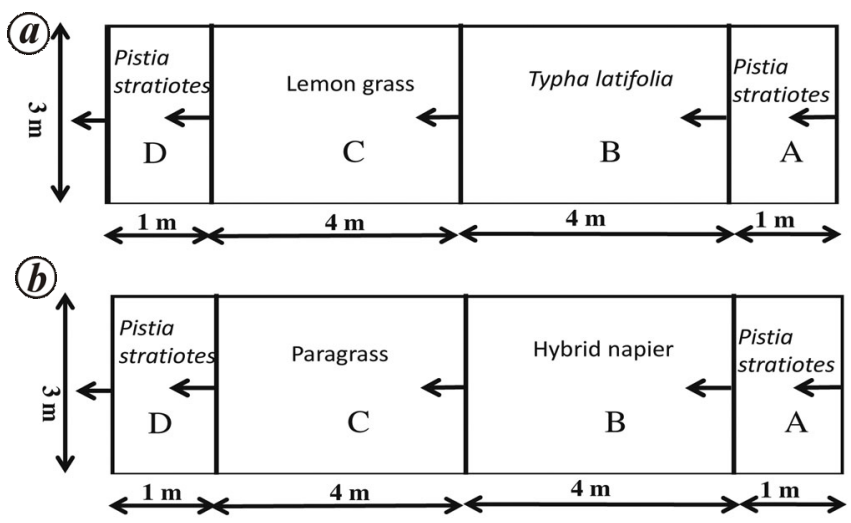

Figure 2. Top view of both field scale subsurface flow CWs with arrows showing the direction of wastewater flow: $\boldsymbol{a}$, first CW showing wetland plant species in each treatment chamber (A-D); (b) Second CW showing wetland plant species in each treatment chambers $(A-D)$.

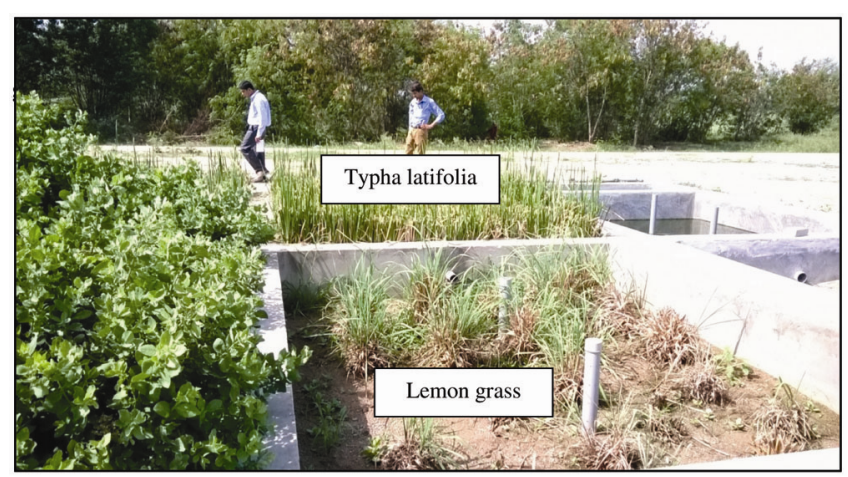

Figure 3. Schematic view of the first field scale subsurface flow CW. 
Table 1. Average calibrated inflow, outflows, HLR and HRT for two subsurface flow CWs

\begin{tabular}{|c|c|c|c|c|c|c|c|c|}
\hline \multirow[b]{2}{*}{ Month } & \multicolumn{2}{|c|}{$\begin{array}{l}\text { Average inlet calibrated } \\
\text { inflows }(1 / \mathrm{min})\end{array}$} & \multicolumn{2}{|c|}{$\begin{array}{l}\text { Average outlet } \\
\text { flows }(1 / \mathrm{min})\end{array}$} & \multicolumn{2}{|c|}{ HLR (cm/day) } & \multicolumn{2}{|c|}{ HRT (days) } \\
\hline & First CW & Second CW & First CW & Second CW & First CW & Second CW & First CW & Second CW \\
\hline January & 1.36 & 0.83 & 1.07 & 0.64 & 6.53 & 3.98 & 11.47 & 18.75 \\
\hline February & 0.44 & 1.64 & 0.17 & 1.39 & 2.11 & 7.87 & 36 & 9.53 \\
\hline March & 0.99 & 1.14 & 0.53 & 0.90 & 4.73 & 5.47 & 15.73 & 13.71 \\
\hline Average & 0.93 & 1.20 & 0.59 & 0.97 & 4.45 & 5.77 & 21 & 14 \\
\hline
\end{tabular}

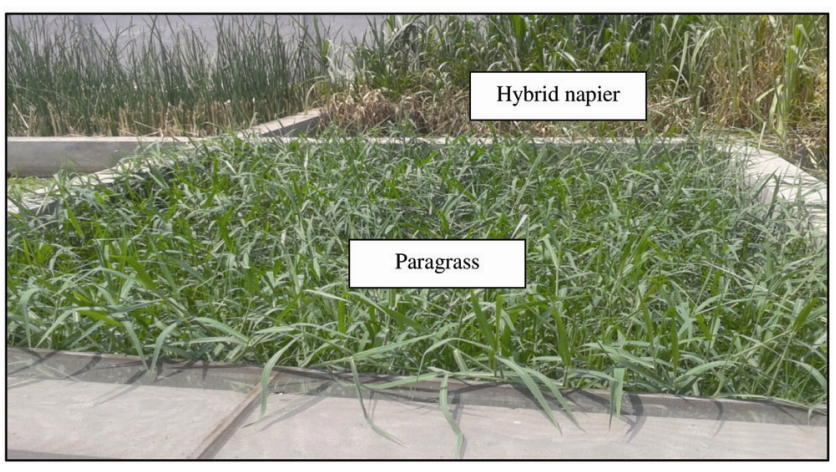

Figure 4. Schematic view of the second field scale subsurface flow CW.

suspended particles were allowed to settle in the inlet tank before entering the CWs. Despite this, the inlet pipes were frequently clogged and U-shaped bends were made in the inlet pipes (Figure $5 b$ ) to reduce clogging. These U-shaped pipe bends were helpful in removing the suspended particles to a certain extent. The inlet pipe had flow regulator (house-old tap) to calibrate the flow. For both CWs, calibrated wastewater inflow rates were different for each month as shown in Table 1. The outlet only had flow meter but there was no flow regulator.

\section{Computing HLR and HRT for CWS}

For computing HLR and HRT, the following equations are used ${ }^{10}$.

$$
\begin{aligned}
& \mathrm{HLR}=\frac{\text { Average flow }(Q) \text { entering CW }}{\text { Surface area (As) of CW }}, \\
& \mathrm{HRT}=\frac{n * L * W * D}{\text { Average flow }(Q) \text { passing through CW }},
\end{aligned}
$$

where $n$ is the media porosity, $L, W$ and $D$ are the length, width and depth respectively of the CW.

\section{Wastewater characterization}

The wastewater samples were collected twice every month and analysed in the ICRISAT laboratory for ammoniacal-nitrogen, nitrate-nitrogen, phosphate, chemical oxygen demand (COD) and total suspended solids (TSS) using the APHA standard methods ${ }^{1-15}$.

\section{Sand and plant sampling}

The sand and plant sampling was carried out each month from January to March for both the CWs. The coarse sand sampling was conducted using a sand auger (Riverside auger-50 cm extension rod, coupling sleeves (2 numbers), and $\mathrm{T}$ handle with rubber grip) manufactured by AIC Agro Instruments (P) Ltd, Kolkata, India. The coarse sand samples were collected from chambers B and $\mathrm{C}$ at depths of $0-5 \mathrm{~cm}$. The sand samples brought to the laboratory were air dried for two days and passed through $2 \mathrm{~mm}$ sieves. The samples were analysed for total nitrogen, total phosphorus, available phosphorus, exchangeable $\mathrm{Ca}$ and $\mathrm{Mg}$. The total nitrogen was analysed using the thiosulphate modification of Kjeldahl method to include nitrate and nitrite ${ }^{16}$. The available $\mathrm{P}$ and the total $\mathrm{P}$ were analysed using the methods given in Olsen and Sommers ${ }^{17}$ and Tandon et al. ${ }^{18}$ respectively. The $\mathrm{Ca}$ and $\mathrm{Mg}$ in the sand media were analysed using the method given in Thomas ${ }^{19}$. For plant sampling, the above-ground biomass was harvested and transported to the laboratory in cloth bags. They were kept in the oven at $65^{\circ} \mathrm{C}$ for $3-4$ days. After drying, the samples were ground using a Willey grinder machine (Nebraska, USA) to a fine powder. The dry weight of the powder was recorded and analysed in the ICRISAT laboratory. The total nitrogen and total phosphorus were analysed using sulphuric acidselenium digestion method ${ }^{20}$. The plant calcium $(\mathrm{Ca})$ and magnesium $(\mathrm{Mg})$ were analysed using the nitric acidhydrogen peroxide digestion ${ }^{21}$.

\section{Results}

\section{Hydrology monitoring}

The results on the hydrologic inflows and outflows associated HLRs and HRT for both CWs are shown in Table 1. The following discussion quantifies how the HLR and HRT affected the effluent wastewater quality in the first and second CW. 


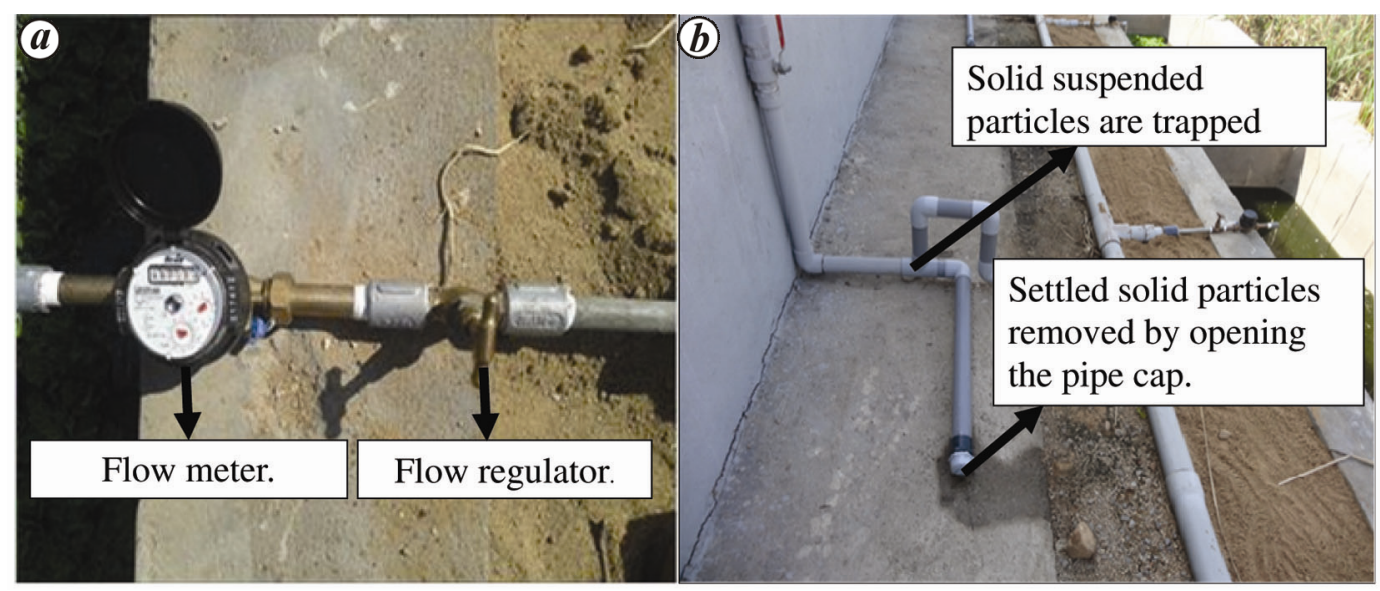

Figure 5. $\boldsymbol{a}$, Itron flow meter and a tap regulator. $\boldsymbol{b}$, U-shaped bend for trapping large particles.

\section{Effect of HLR and HRT on effluent wastewater characteristics}

Inlet wastewater concentrations for both CWs: The mean inlet concentrations of COD, TSS, $\mathrm{NH}_{4}-\mathrm{N}, \mathrm{NO}_{3}-\mathrm{N}$ and phosphate in January were $144 \mathrm{mg} / 1,54 \mathrm{mg} / \mathrm{l}$, $96 \mathrm{mg} / 1,2.76 \mathrm{mg} / \mathrm{l}$ and $3.62 \mathrm{mg} / \mathrm{l}$ respectively. The mean inlet concentrations of COD, TSS, $\mathrm{NH}_{4}-\mathrm{N}, \mathrm{NO}_{3}-\mathrm{N}$ and phosphate in February were $192 \mathrm{mg} / 1,38 \mathrm{mg} / 1,63 \mathrm{mg} / \mathrm{l}$, $2.91 \mathrm{mg} / \mathrm{l}$ and $4.12 \mathrm{mg} / \mathrm{l}$ respectively.

Effluent wastewater concentrations for first $C W$ : The mean effluent concentrations of COD, TSS, $\mathrm{NH}_{4}-\mathrm{N}$, $\mathrm{NO}_{3}-\mathrm{N}$ and phosphate in January were $64 \mathrm{mg} / 1,8 \mathrm{mg} / \mathrm{l}$, $62 \mathrm{mg} / 1,1.69 \mathrm{mg} / \mathrm{l}$ and $3.55 \mathrm{mg} / \mathrm{l}$ respectively. The mean percentage reductions for COD, TSS, $\mathrm{NH}_{4}-\mathrm{N}, \mathrm{NO}_{3}-\mathrm{N}$ and phosphate in January were 55\%, 85\%, 35\%, 39\% and 2\% respectively. The mean effluent concentrations of COD, TSS, $\mathrm{NH}_{4}-\mathrm{N}, \mathrm{NO}_{3}-\mathrm{N}$ and phosphate in February were $64 \mathrm{mg} / \mathrm{l}, 4 \mathrm{mg} / \mathrm{l}, 28 \mathrm{mg} / \mathrm{l}, 2.33 \mathrm{mg} / \mathrm{l}$ and $1.05 \mathrm{mg} / \mathrm{l} \mathrm{respec}-$ tively. The mean percentage reduction in February was $66 \%, 89 \%, 55 \%, 20 \%$ and $75 \%$ respectively.

Effluent wastewater concentrations for second $C W$ : The mean effluent concentrations of COD, TSS, $\mathrm{NH}_{4}-\mathrm{N}$, $\mathrm{NO}_{3}-\mathrm{N}$ and phosphate in January were $96 \mathrm{mg} / 1,2 \mathrm{mg} / \mathrm{l}$, $71 \mathrm{mg} / 1,1.70 \mathrm{mg} /$ land $2.93 \mathrm{mg} / 1$ respectively. The mean percentage reduction for COD, TSS, $\mathrm{NH}_{4}-\mathrm{N}, \mathrm{NO}_{3}-\mathrm{N}$ and phosphate in January were $33 \%, 96 \%, 26 \%, 38 \%$ and $19 \%$ respectively. The mean effluent concentrations of COD, TSS, $\mathrm{NH}_{4}-\mathrm{N}, \mathrm{NO}_{3}-\mathrm{N}$ and phosphate in February were $144 \mathrm{mg} / 1,8 \mathrm{mg} / 1,41 \mathrm{mg} / 1,2.14 \mathrm{mg} / 1$ and $4.03 \mathrm{mg} / 1$ respectively. The mean percentage reduction in February was $25 \%, 78 \%, 35 \%, 26 \%$ and $2.2 \%$ respectively.

Hydrologic comparisons of first and second $C W$ : In the first $\mathrm{CW}$, the $\mathrm{COD}$, TSS, $\mathrm{NH}_{4}-\mathrm{N}$ and phosphate reductions were considerably greater in February compared to January. This was due to the lower HLR and greater HRT in February compared to January (Table 1). In the second
$\mathrm{CW}$, the COD, TSS, $\mathrm{NO}_{3}-\mathrm{N}$ and phosphate removals were greater in January due to low HLR and higher HRT compared to that in February (Table 1). The average HLR and the average HRT for the first and second CW for the three-month period were $4.45 \mathrm{~cm} /$ day and 21 days and $5.77 \mathrm{~cm} /$ day and 14 days respectively (Table 1).

\section{Wastewater characterization}

Tables 2 and 3 show the untreated wastewater and the treated wastewater parameters respectively for both CWs and they consisted of TSS, COD, total nitrogen and total phosphate. The treatment efficiency of each parameter for both CWs is compared with the literature values.

\section{Total suspended solids (TSS)}

In the first $\mathrm{CW}$, average inlet and outlet TSS concentrations were $38.5 \mathrm{mg} / \mathrm{l}$ and $10 \mathrm{mg} / \mathrm{l}$ respectively, with a reduction efficiency of $74 \%$. In the second $\mathrm{CW}$, the outlet TSS concentration was $7 \mathrm{mg} / \mathrm{l}$ with a reduction efficiency of $82 \%$. These results showed that irrespective of the type of wetland plants, both the CWs had similar removal efficiencies. The treated wastewater having TSS levels less than $30 \mathrm{mg} / \mathrm{l}$ can be used in agriculture for growing food crops $^{22}$. A pilot scale study evaluated the treatment efficiency of four horizontal subsurface flow CWs in a threestage system over a 6 -year period ${ }^{23}$. The TSS reduction was $95 \%$. Another pilot scale experiment used three wetland species (Schoenoplectus validus, Juncusingens or both species of macrophytes) and one control ${ }^{24}$. The total TSS reduction observed over a 10 -month period was $85 \%$. The results obtained in this study with regard to TSS removals are similar to those reported in the literature.

\section{Chemical oxygen demand (COD)}

The average inlet COD was $148 \mathrm{mg} / \mathrm{l}$ with a maximum and minimum value of $224 \mathrm{mg} / \mathrm{l}$ and $64 \mathrm{mg} / \mathrm{l}$ respectively 
(Table 2). The average outlet COD for the first and second $\mathrm{CW}$ was $87 \mathrm{mg} / \mathrm{l}$ and $102 \mathrm{mg} / \mathrm{l}$ having a reduction efficiency of $41 \%$ and $31 \%$ respectively. A pilot scale subsurface flow $\mathrm{CW}$ having wastewater source from an upflow anaerobic sludge blanket (UASB) reactor quantified COD removal rates for control, Phragmites mauritianus and Typha latifolia respectively. Results showed removal rates to be $33.6 \%, 56.3 \%$ and $60.7 \%$ for control, Phragmites mauritianus and Typha latifolia respectively ${ }^{25}$. The present results are comparable with the above study from the literature.

\section{Nitrogen and phosphate removals}

The average inlet total nitrogen was $3.8 \mathrm{meq} / 1$ and the outlet total nitrogen in the first and second $\mathrm{CW}$ averaged $2.33 \mathrm{meq} / 1$ and $3.26 \mathrm{meq} / 1$ respectively (Tables 2 and 3 ). The total nitrogen reduction efficiency of the first and second CW averaged 39\% and 14\% respectively over a three-month period. The average inlet phosphate concentration was $4.6 \mathrm{mg} / \mathrm{l}$ and the outlet phosphate concentration in the first and second $\mathrm{CW}$ averaged $2.7 \mathrm{mg} / 1$ and $3 \mathrm{mg} / \mathrm{l}$ respectively. The phosphate reduction efficiency of the first and second CW was $41 \%$ and $35 \%$ respectively (Tables 2 and 3). A subsurface flow CWs was used to treat swine wastewater under different HRTs (8.5 day, 4.3 day and 14.7 day). The total nitrogen and total phosphorus removals averaged $10-24 \%$ and $47-59 \%$ respectively $^{26}$. Schulz et al. ${ }^{27}$ used emergent plants in a CW study for treating aquaculture effluents. Results showed that the total nitrogen and total phosphorus removals averaged $20-41 \%$ and $49-68.5 \%$ respectively. The total nitrogen and phosphate removals in this study are similar to the literature values.

\section{Nitrogen and phosphorus accumulation in sand media}

First $C W$ : We measured the accumulation of total nitrogen and phosphorus in the pre-treatment and the posttreatment sand media in both CWs (Table 4). The average total nitrogen accumulation in treatments $\mathrm{B}$ and $\mathrm{C}$ increased by $48 \%$ and $4 \%$ respectively, while the average

Table 2. Characteristics of untreated wastewater used in the study

\begin{tabular}{lccc}
\hline Parameters & $\begin{array}{c}\text { Average } \\
\text { value }\end{array}$ & $\begin{array}{c}\text { Maximum } \\
\text { value }\end{array}$ & $\begin{array}{c}\text { Minimum } \\
\text { value }\end{array}$ \\
\hline TSS (mg/l) & 38.5 & 64 & 4 \\
COD (mg/l) & 148 & 224 & 64 \\
Phosphate (mg/l) & 4.6 & 23 & 2.39 \\
Total nitrogen (meq/l) & 3.8 & 6.08 & 0.033 \\
\hline
\end{tabular}

TSS, Total suspended solids; COD, Chemical oxygen demand; Average, max. and min. value of 19 samples represented over a 3-month period (January-March 2015). total phosphorus accumulation in treatments $\mathrm{B}$ and $\mathrm{C}$ increased by $74 \%$ and $54 \%$ respectively (Table 4 ). The average available $\mathrm{P}$, a nutrient source for plants, also increased in the treatments $\mathrm{B}$ and $\mathrm{C}$ by $93 \%$ and $88 \%$ respectively. There was no change in the exchangeable $\mathrm{Ca}$ between the pre-treatment and the post-treatment sand media in both CWs. However, the exchangeable $\mathrm{Mg}$ in the treatments $\mathrm{B}$ and $\mathrm{C}$ increased by $25 \%$ and $42 \%$ respectively in the post-treatment compared to pretreatments and media.

Second $C W$ : The average total nitrogen accumulation in treatments $\mathrm{B}$ and $\mathrm{C}$ increased by $68 \%$ and $58 \%$ respectively, while the average total phosphorus accumulation in treatments B and C increased by $74 \%$ and $62 \%$ respectively (Table 4). The average available $\mathrm{P}$, a nutrient source for plants, also increased by $93 \%$ and $93 \%$ in treatments $\mathrm{B}$ and $\mathrm{C}$ respectively compared to available $\mathrm{P}$ of the pre-treatment sample (Table 4). However, the exchangeable $\mathrm{Mg}$ in treatments $\mathrm{B}$ and $\mathrm{C}$ increased by $47 \%$ and $50 \%$ respectively in post-treatment compared to pre-treatment sand media.

\section{Nitrogen and phosphorus accumulation comparison with literature}

The total nitrogen and phosphorus accumulation in this field scale study ranged from 0.15 to $0.47 \mathrm{~g} / \mathrm{kg}$ and 0.11 to $0.17 \mathrm{~g} / \mathrm{kg}$ respectively, over a three-month period. A study showed that the total nitrogen accumulation in two CWs averaged $0.7-0.9 \mathrm{~g} / \mathrm{kg}$ (ref. 28). The higher total nitrogen accumulation in the above study was due to a higher HRT of 20-21 days compared to the retention time averaging 14 days in the second CW. A subsurface flow $\mathrm{CW}$ study ${ }^{29}$ reported phosphorus accumulation in 13 Danish sands ranging from 0.04 to $0.45 \mathrm{~g} / \mathrm{kg}$.

\section{Nitrogen and phosphorus uptake in wetland plants}

Pistia stratiotes: The inlet and outlet treatment chambers of the first and second CW contained Pistia stratiotes. The nitrogen content of Pistia stratiotes included its leaves and roots (whole plant nutrient content together). The nitrogen contents in Pistia stratiotes in the inlet and outlet chamber for the first $\mathrm{CW}$ averaged $37.4 \mathrm{~g} / \mathrm{kg}$ and $33.5 \mathrm{~g} / \mathrm{kg}$, and in the second $\mathrm{CW}$ it averaged $42.8 \mathrm{~g} / \mathrm{kg}$ and $33.9 \mathrm{~g} / \mathrm{kg}$ respectively. The phosphorus contents in Pistia stratiotes in the inlet and outlet chamber for the first CW averaged $8.4 \mathrm{~g} / \mathrm{kg}$ and $9.46 \mathrm{~g} / \mathrm{kg}$, and in the second $\mathrm{CW}$ it averaged $9.47 \mathrm{~g} / \mathrm{kg}$ and $7.89 \mathrm{~g} / \mathrm{kg}$ respectively (Table 5). Polomski et al. ${ }^{30}$ quantified nitrogen and phosphorus uptake of Pistia stratiotes in a laboratory scale CW study. Results showed that the average nitrogen and phosphorus contents were $16.21 \mathrm{~g} / \mathrm{kg}$ and $2.3 \mathrm{~g} / \mathrm{kg}$, 
SPECIAL SECTION: SOIL AND WATER MANAGEMENT

Table 3. Treated wastewater characteristics from first and second subsurface flow CW

\begin{tabular}{|c|c|c|c|c|c|c|}
\hline \multirow[b]{2}{*}{ Parameters } & \multicolumn{2}{|c|}{ Average value } & \multicolumn{2}{|c|}{ Max. value } & \multicolumn{2}{|c|}{ Min. value } \\
\hline & First CW & Second CW & First CW & Second CW & First CW & Second CW \\
\hline TSS (mg/l) & 10 & 7 & 16 & 12 & 4 & 2 \\
\hline COD (mg/1) & 87 & 102 & 128 & 192 & 64 & 64 \\
\hline Phosphate (mg/l) & 2.7 & 3 & 3.84 & 4.03 & 1.05 & 2.93 \\
\hline Total nitrogen (meq/1) & 2.33 & 3.26 & 3.96 & 4.00 & 0.0272 & 0.03 \\
\hline
\end{tabular}

TSS, Total suspended solids; COD, Chemical oxygen demand. Average, max. and min. value of 19 samples represented over a 3-month period (January-March 2015).

Table 4. Nutrient accumulation in sand media for the first and second CW

\begin{tabular}{|c|c|c|c|c|c|c|c|c|c|c|}
\hline \multirow[b]{2}{*}{ Treatment chambers } & \multicolumn{2}{|c|}{ Total N (g/kg) } & \multicolumn{2}{|c|}{ Total P (g/kg) } & \multicolumn{2}{|c|}{ Available P (g/kg) } & \multicolumn{2}{|c|}{ Exch Ca (g/kg) } & \multicolumn{2}{|c|}{ Exch Mg (g/kg) } \\
\hline & First CW & Second CW & First CW & Second CW & First CW & Second CW & First CW & Second CW & First CW & Second CW \\
\hline B1 & 0.39 & 0.59 & 0.19 & 0.17 & 0.008 & 0.010 & 0.93 & 0.84 & 0.096 & 0.096 \\
\hline B1 & 0.47 & 0.79 & 0.18 & 0.23 & 0.019 & 0.036 & 1.00 & 0.98 & 0.123 & 0.220 \\
\hline B1 & 0.16 & 0.23 & 0.10 & 0.12 & 0.019 & 0.011 & 0.90 & 0.97 & 0.084 & 0.108 \\
\hline B1 & 0.13 & 0.27 & 0.21 & 0.13 & 0.011 & 0.003 & 0.89 & 0.88 & 0.077 & 0.111 \\
\hline Average & 0.29 & 0.47 & 0.173 & 0.168 & 0.014 & 0.015 & 0.93 & 0.921 & 0.095 & 0.134 \\
\hline $\mathrm{C} 1$ & 0.17 & 0.61 & 0.13 & 0.14 & 0.005 & 0.013 & 0.95 & 0.88 & 0.093 & 0.144 \\
\hline $\mathrm{C} 1$ & 0.15 & 0.54 & 0.093 & 0.15 & 0.008 & 0.019 & 0.99 & 0.98 & 0.135 & 0.256 \\
\hline $\mathrm{C} 1$ & 0.19 & 0.13 & 0.064 & 0.072 & 0.013 & 0.022 & 0.99 & 0.98 & 0.157 & 0.077 \\
\hline $\mathrm{C} 1$ & 0.10 & 0.14 & 0.094 & 0.085 & 0.004 & 0.007 & 0.95 & 0.85 & 0.105 & 0.091 \\
\hline Average & 0.15 & 0.357 & 0.095 & 0.115 & 0.008 & 0.015 & 0.97 & 0.928 & 0.122 & 0.142 \\
\hline
\end{tabular}

respectively. The nitrogen and phosphorus removal by Pistia stratiotes in this study is comparable to the above study.

Typha latifolia (cattail) and Cymbopogon citratus (lemon grass) (first $\mathrm{CW}$ ): The nitrogen and phosphorus content in the Typha latifolia averaged $27.1 \mathrm{~g} / \mathrm{kg}$ and $2.96 \mathrm{~g} / \mathrm{kg}$ respectively over a three-month period (Table 5). The nitrogen and phosphorus uptake of Typha latifolia evaluated in a $\mathrm{CW}$ which received winery wastewater averaged $11.68 \mathrm{~g} / \mathrm{kg}$ and $0.31 \mathrm{~g} / \mathrm{kg}$ respectively $^{31}$. Costa et al. ${ }^{32}$ evaluated the nitrogen and phosphorus removals of Typha latifolia in a subsurface flow $\mathrm{CW}$ receiving effluent wastewater from a trickling filter unit. Results showed that the aboveground nitrogen and phosphorus contents averaged $24 \mathrm{~g} / \mathrm{kg}$ and $4.4 \mathrm{~g} / \mathrm{kg}$ respectively. The nitrogen and phosphorus uptake of Typha latifolia in our study are comparable to the literature values. The average nitrogen and the phosphorus contents in the aboveground biomass of Cymbopogon citratus averaged $15.8 \mathrm{~g} / \mathrm{kg}$ and $2.29 \mathrm{~g} / \mathrm{kg}$ respectively. This is the first report of the aboveground nitrogen and phosphorus uptake of lemon grass in a $\mathrm{CW}$.

Pennisetum purpureum schum and Pennisetum americanum L (hybrid napier) and Urochloa mutica (paragrass) (second $C W$ ): The average nitrogen and phosphorus uptake of hybrid napier in this study averaged
$22.2 \mathrm{~g} / \mathrm{kg}$ and $2.84 \mathrm{~g} / \mathrm{kg}$ respectively. The nitrogen and phosphorus contents in the paragrass averaged $34 \mathrm{~g} / \mathrm{kg}$ and $8.87 \mathrm{~g} / \mathrm{kg}$ respectively (Table 5). However, there is lack of data in the literature with regard to nitrogen and phosphorus uptake of paragrass and hybrid napier in CWs receiving domestic/industrial wastewater. This field scale CW study is the first on report on the aboveground nitrogen and phosphorus uptake of the above two species.

\section{Effect of plant harvesting on nitrogen and phosphorus uptake}

In the first $\mathrm{CW}$, the increase in nitrogen and phosphorus contents of Pistia stratiotes on 31 March with respect to its contents on 17 March was $63 \%$ and $62 \%$ respectively (Table 5). This increase was due to harvesting of Pistia stratiotes on 11 March 2015. The Typha latifolia was harvested on 18 February and the nitrogen and phosphorus contents were significantly greater on 17 March compared to 24 February. The percentage increase in nitrogen and phosphorus contents on 17 March compared to its contents on 24 February were $62 \%$ and $58 \%$ respectively (Table 5). The Cymbopogon citratus was harvested on 10 February and results showed that nitrogen and phosphorus contents were greater on 17 March compared to 17 February by $74 \%$ and $42 \%$ respectively (Table 5). 
Table 5. Nutrient accumulation in the wetland plants for the first and second CW

\begin{tabular}{|c|c|c|c|c|c|c|}
\hline \multirow[b]{2}{*}{ Sampling date } & \multicolumn{3}{|c|}{ First CW } & \multicolumn{3}{|c|}{ Second CW } \\
\hline & Plant type & Total N (g/kg) & Total P (g/kg) & Plant type & Total N (g/kg) & Total P $(\mathrm{g} / \mathrm{kg})$ \\
\hline 9 January & Pistia stratiotes & 41.5 & 10.2 & Pistia stratiotes & 49.2 & 12.6 \\
\hline 17 February & & 43 & 10.7 & & 46.2 & 11.3 \\
\hline 17 March & & 17.6 & 3.5 & & 29.7 & 5.8 \\
\hline 31 March & & 47.4 & 9.1 & & 46.0 & 8.03 \\
\hline Average & & 37.4 & 8.4 & & 42.8 & 9.47 \\
\hline 9 January & Typha latifolia & 25.7 & 2.7 & Hybrid napier & 18.5 & 2.65 \\
\hline 24 February & & 13.4 & 1.7 & & 20.1 & 2.33 \\
\hline 17 March & & 35.7 & 4.1 & & 24.2 & 2.84 \\
\hline 31 March & & 33.6 & 3.2 & & 25.9 & 3.55 \\
\hline Average & & 27.1 & 2.96 & & 22.2 & 2.84 \\
\hline 9 January & Lemon grass & 9.8 & 1.9 & Paragrass & NA & NA \\
\hline 17 February & & 6.2 & 1.4 & & 18.9 & 2.71 \\
\hline 17 March & & 24.1 & 2.4 & & 40.4 & 11.6 \\
\hline 31 March & & 23.1 & 3.36 & & 42.6 & 12.3 \\
\hline Average & & 15.8 & 2.29 & & 34.0 & 8.87 \\
\hline 9 January & Pistia stratiotes & 37.2 & 10.0 & Pistia stratiotes & NA & NA \\
\hline 17 February & & 30.7 & 11.2 & & 45.3 & 12.03 \\
\hline 17 March & & 30.1 & 6.2 & & 16.3 & 3.48 \\
\hline 31 March & & 36.1 & 10.3 & & 40 & 8.16 \\
\hline Average & & 33.5 & 9.46 & & 33.9 & 7.89 \\
\hline
\end{tabular}

*NA, Not available.

In the second $\mathrm{CW}$, the increase in nitrogen and phosphorus contents of Pistia stratiotes on 31 March compared with that on 17 March was $35 \%$ and $37 \%$ respectively (Table 5). This increase was due to harvesting of Pistia stratiotes on 11 March 2015. The hybrid napier was not harvested in the three-month monitoring period. The nitrogen and phosphorus contents of paragrass increased from $18.9 \mathrm{~g} / \mathrm{kg}$ to $42.6 \mathrm{~g} / \mathrm{kg}$ and $2.71 \mathrm{~g} / \mathrm{kg}$ to $12.3 \mathrm{~g} / \mathrm{kg}$ from 17 February to 31 March. Paragrass was established in the second CW on 17 February 2015 and its nitrogen and phosphorus uptake increased by $56 \%$ and $78 \%$ over a period of 44 days. This showed that paragrass can be successfully established in $\mathrm{CW}$ and showed good potential for nitrogen and phosphorus uptake.

\section{Discussion}

\section{Mechanism of TSS and COD removal in both CWS}

The major principle of TSS and COD removals in CWs is the sedimentation, filtration and physical entrapment in the void pores of the sand and gravel media ${ }^{33}$. The higher HRT allows for greater physical settling of suspended particles, which reduces the TSS and the higher residence time allows wetland plants to effectively uptake nutrients thereby reducing the effluent concentrations. Besides sedimentation and settling, a reduction in suspended solids can be due to van der Waals forces of attraction which can attract or repulse based on surface charges ${ }^{34}$.

\section{Mechanisms of $\mathrm{NH}_{4}-\mathrm{N}$ and $\mathrm{NO}_{3}-\mathrm{N}$ removal in both CWs}

Ammonia volatilization is the process where $\mathrm{NH}_{4}-\mathrm{N}$ is in equilibrium between gaseous and liquid forms. Ammonium volatilization is generally insignificant if wastewater $\mathrm{pH}$ is below 7.5 and low for $\mathrm{pH} 7.5-8$ (ref. 35). Significant volatilization occurs if the $\mathrm{pH}$ is higher than 9.3. In the first $\mathrm{CW}$, the $\mathrm{pH}$ in all the treatment chambers was 7.5-8.5 (data not shown). From these measured $\mathrm{pH}$ values, ammonia volatilization was probably not the major mechanism of nitrogen loss. Ammonium ion $\left(\mathrm{NH}_{4}^{+}\right)$is adsorbed as exchangeable ion on clays and organic matter. The adsorbed $\mathrm{NH}_{4}^{+}$is loosely attached to the sand particles and released into the wastewater upon subject to changing water chemistry. For example, in case of alternate flooding and drying, the adsorbed ammonium attached to the sand particle can increase and in case of drying the adsorbed $\mathrm{NH}_{4}-\mathrm{N}$ is converted into $\mathrm{NO}_{3}-\mathrm{N}$ in the presence of aerobic conditions ${ }^{36}$. Mineralization rates are dependent upon $\mathrm{pH}(6.5-8.5)$, temperature $\left(40-60^{\circ} \mathrm{C}\right)$, $\mathrm{C} / \mathrm{N}$ ratio, available nutrients, texture and structure of soil media. The $\mathrm{pH}$ of wastewater in this study was in the optimal range and inlet wastewater had high $\mathrm{NH}_{4}-\mathrm{N}$ concentrations varying from 30 to $109 \mathrm{mg} / \mathrm{l}$ over a threemonth period. Both the $\mathrm{CWs}$ had inlet $\mathrm{NO}_{3}-\mathrm{N}$ concentrations ranging from 1.08 to $3.9 \mathrm{mg} / \mathrm{l}$ and the production of $\mathrm{NO}_{3}-\mathrm{N}$ inside the treatment chambers $(1.69-3.08 \mathrm{mg} / \mathrm{l})$ was considerably lower compared to $\mathrm{NH}_{4}-\mathrm{N}$. The important factors affecting nitrification are temperature 
$\left(30-40^{\circ} \mathrm{C}\right), \mathrm{pH}(6.6-8.0)$, alkalinity, $\mathrm{C}$ source, moisture, microbial population, $\mathrm{NH}_{4}-\mathrm{N}$ and dissolved oxygen. In this study, temperature and $\mathrm{pH}$ varied from $19.7^{\circ} \mathrm{C}$ to $27^{\circ} \mathrm{C}$ and 7.5 to 9 respectively and were not in the range given above. The $\mathrm{pH}$ and temperature are point scale readings taken at one particular time (no continuous measurements were done) and they only provide a snap shot, but do not represent the entire picture of a CW. Also the nitrate produced might be undergoing denitrification as the $\mathrm{pH}$ and temperature were suitable for denitrification. Denitrification is the conversion of $\mathrm{NO}_{3}-\mathrm{N}$ into dinitrogen gas through a series of intermediate process nitrite, nitric oxide and nitrous oxide ${ }^{37}$. It requires $\mathrm{NO}_{3}-\mathrm{N}$ as the electron acceptor, available organic substrate, absence of $\mathrm{O}_{2}$, temperature, presence of denitrifiers and suitable Eh conditions (anoxic or anaerobic) ranging from $+100 \mathrm{mV}$ to $+350 \mathrm{mV}$, optimum $\mathrm{pH}$ from 6 to 8 . In this study, conditions were probably favourable for denitrification, $\mathrm{pH}$ ranging from 7 to 8.5 , Eh varying between 120 and $190 \mathrm{mV}$, Eh less than $300 \mathrm{mV}$ (anoxic conditions), and presence of $\mathrm{NO}_{3}-\mathrm{N}$ for denitrification to occur. Though denitrification at this site was not quantified, it could be the major $\mathrm{N}$ loss mechanism for both the CWs.

\section{Mechanisms of phosphorus removal in both CWs}

Major mechanisms of phosphorus removal in CWs are the plant and microbial uptake, and retention/adsorption onto sand media. Adsorption/retention of phosphorus is controlled by redox potential, $\mathrm{pH}$ and exchangeable $\mathrm{Ca}$, $\mathrm{Mg}$ and $\mathrm{Fe}$. At $\mathrm{pH}$ greater than 7, phosphorus is adsorbed onto insoluble calcium $(\mathrm{Ca}-\mathrm{P})$. $\mathrm{P}$ sorption takes place in two steps: (i) exchange of phosphate between the soilwater and soil particles (adsorption); (ii) the phosphate then slowly penetrates into the solid phase ${ }^{38}$. The phosphorus can also be released from the wetland soils in case of high anaerobic conditions (reduction of $\mathrm{Fe}$ (III) and $\mathrm{Mn}(\mathrm{IV})$ ). The solubility of the adsorbed $\mathrm{P}$ to the wetland soils is influenced by the $\mathrm{pH}$ and the oxidation reduction potential (ORP). For a wastewater $\mathrm{pH}$ varying from 5 to 8 , solubility of $\mathrm{P}$ is low if ORP is $300 \mathrm{mV}$ resulting in lower concentration in soil pore water. As the ORP decreases from $+300 \mathrm{mV}$ to $-250 \mathrm{mV}$, the $\mathrm{P}$ solubility increases and so does its concentration in the soil porewater. In both the CWs, results showed that most of the phosphate bonded with exchangeable $\mathrm{Ca}$ as the soluble $\mathrm{P}$ was 10.6 times lower in magnitude than the total $\mathrm{P}$ (Table 4). The ORP in both CWs varied from 120 to $190 \mathrm{mV}$ and the wastewater $\mathrm{pH}$ varied from 7.5 to 8.5 for the threemonth period. These conditions will result in lower availability of $\mathrm{P}$ in the pore water and greater $\mathrm{P}$ adsorbed to exchangeable $\mathrm{Ca}$ and $\mathrm{Mg}$.

\section{Conclusions}

The first CW with Pistia stratiotes, Typha latifolia and lemon grass attenuated more nitrogen and phosphorus compared to the second CW with Pistia stratiotes, hybrid napier and paragrass. The high nitrogen and phosphorus removal in the first $\mathrm{CW}$ compared to the second $\mathrm{CW}$ were due to the low average HLR and the high average HRT. Pistia stratiotes was the highest accumulator of nitrogen and phosphorus, followed by paragrass, Typha latifolia, hybrid napier and the lemon grass. It is critically important that wetland species should be regularly harvested to maximize their nitrogen and phosphorus uptake capacities. This study showed that field scale subsurface flow CWs are a viable tool for improving wastewater quality in rural parts of India.

1. Vymazal, J., Horizontal sub-surface flow and hybrid constructed wetlands systems for wastewater treatment. Ecol. Eng., 2005, 25, 478-490.

2. Scholes, L. N. L., Shutes, R. B. E., Revitt, D. M., Purchase, D. and Forshaw, M., The removal of urban pollutants by constructed wetlands during wet weather. Water Sci Technol., 1999, 40, 33, 333340 .

3. Shelef, O., Gross, A. and Rachmilevitch, S., Role of plants in a constructed wetland: current and new perspectives. Water, 2013, 5, 405-419.

4. Stefanakis, A., Akratos, C. and Tsihrintzis, S., Vertical Flow Constructed Wetlands: Eco-engineering Systems for Wastewater and Sludge Treatment, Elsevier Science Publishing Co Inc, 2015, 1st edn.

5. Brix, H., Do macrophytes play a role in constructed treatment wetlands? Water Sci. Technol., 1997, 35, 11-17.

6. Cooke, J. G., Nutrient transformations in a natural wetland receiving sewage effluent and the implications for waste treatment. Water Sci. Technol., 1994, 29, 209-217.

7. Tanner, C. C., Clayton, J. S. and Upsdell, M. P., Effect of loading rate and planting on treatment of dairy farm wastewaters in constructed wetlands - I. Removal of oxygen demand, suspended solids and faecal coliforms. Water Resources, 1995, 29, 17-26.

8. Vymazal, J., Removal of nutrients in various types of constructed wetlands. Sci. Total Environ., 2007, 380, 48-65.

9. Klomjek, P. and Nitisoravut, S., Constructed treatment wetland: a study of eight plant species. Chemosphere, 2005, 58, 585-593.

10. United States Environmental Protection Agency (USEPA), Manual for Constructed Wetlands Treatment of Municipal Wastewaters, EPA/625/R-99/010, Cincinnati, USEPA, 2000.

11. APHA, Standard Methods for the Examination of Water and Wastewater, 4500-NH3 F, American Public Health Association (APHA), Washington, DC, 2005, 21 st edition.

12. APHA, Standard Methods for the Examination of Water and Wastewater, 4500-NO3 B, American Public Health Association, Washington, DC, 2005, 21 st edition.

13. APHA, Standard Methods for the Examination of Water and Wastewater, 4500-P D, American Public Health Association, Washington, DC, 2005, 21 st edition.

14. APHA, Standard Methods for the Examination of Water and Wastewater, 5220-C, American Public Health Association, Washington, DC, 2005, 21 st edition.

15. APHA, Standard Methods for the Examination of Water and Wastewater, 2540-D, American Public Health Association, Washington, DC, 2005, 21 st edition.

16. Dalal, R. C., Sahrawat, K. L. and Myers, R. J. K., Inclusion of nitrate in the Kjeldahl nitrogen determination of soils and plant materials using sodium thiosulphate. Commun. Soil Sci. Plant Anal., 1984, 15, 1453-1461.

17. Olsen, S. R. and Sommers, L. E., Phosphorus. In Methods of Soil Analysis (eds Page, A. L., Miller, R. H. and Keeney, D. R.), 


\section{SPECIAL SECTION: SOIL AND WATER MANAGEMENT}

American Society of Agronomy and Soil Science Society of America, Madison, Wisconsin, USA, 1982, pp. 403-430, part II, 2nd edn.

18. Tandon, H. L. S., Cescas, M. P. and Tyner, E. H., An acid free vanadate-molybdate reagent for the determination of total phosphorus in soils. Soil Sci. Soc. Am. Proc., 1962, 32, 48-51.

19. Thomas, G. W., Exchangeable cations. In Methods of Soil Analysis (eds Page, A. L., Miller, R. H. and Keeney, D. R.), American Society of Agronomy and Soil Science Society of America, Madison, Wisconsin, USA, 1982, pp. 159-165, Part II, 2nd edition.

20. Sahrawat, K. L., Kumar G. R. and. Murthy, K. V. S., Sulfuric acid-selenium digestion for multi-element analysis in a single plant digest. Commun. Soil Sci. Plant Anal., 2002, 33, 3757-3765.

21. Matthew, S. W., Fowles, T. O. and Palmer, L. T., A cost-effective acid digestion method using closed polypropylene tubes for inductively coupled optical emission spectrometry (ICP-OES) analysis of plant essential elements. Anal. Methods, 2011, 3, 2854-2863.

22. United States Environmental Protection Agency (USEPA), Office of wastewater management, Report to congress: clean water needs survey, 2000, 2004

23. Merlin, G., Pajean, J. L. and Lissolo, T., Performances of constructed wetlands for municipal wastewater treatment in rural mountainous area. Hydrobiologia, 2002, 469, 87-98.

24. Thomas, P. R., Glover, P. and Kalaroopan, T., An evaluation of pollutant removal from secondary treated sewage effluent using a constructed wetland system. Water Sci. Technol., 1995, 32, 87-93.

25. Kaseva, M. E., Performance of a sub-surface flow constructed wetland in polishing pre-treated wastewater-a tropical case study. Water Res., 2004, 38, 681-687.

26. Lee, C. Y., Lee, C. C., Lee, F. Y., Tseng, S. K. and Liao, C. J., Performance of subsurface flow constructed wetland taking pretreated swine effluent under heavy loads. Bio-resource Technol., 2004, 92, 173-179.

27. Schulz, C., Gelbrecht, J. and Rennert, B., Treatment of rainbow trout farm effluents in constructed wetland with emergent plants and subsurface horizontal water flow. Aquaculture, 2003, 217, 207-221.

28. Gale, P. M., Reddy, K. R. and Graetz, D. A., Nitrogen removal from reclaimed water applied to constructed and natural wetland microcosms. Water Environ. Res., 1993, 65, 162-168.

29. Brix, H., Arias, C. A. and Del Bubba, M., Media selection for sustainable phosphorus removal in subsurface flow constructed wetlands. Water Sci. Technol., 2001, 44, 47-54.
30. Polomski, R. F., Taylor, M. D., Bielenberg, D. G., Bridges, W. C., Klaine, S. J. and Whitwell, T., Nitrogen and phosphorus remediation by three floating aquatic macrophytes in greenhouse-based laboratory-scale subsurface constructed wetlands. Water, Air, Soil Pollut., 2009, 197, 223-232.

31. Zingelwa, N. and Wooldridge, J., Tolerance of macrophytes and grasses to sodium and chemical oxygen demand in winery wastewater. South Afr. J. Enol. Vitic., 2009, 30, 117-123.

32. Costa, J. F., Martins, W. L. P., Martin, S. and Sperling, M., Role of vegetation (Typha latifolia) on nutrient removal in a horizontal subsurface-flow constructed wetland treating UASB reactortrickling filter effluent. Water Sci. Technol., 2015, 71, 1004-1010; doi: 10.2166/wst.2015.055.

33. Kadlec, R. H., Comparison of free water and horizontal subsurface treatment wetlands. Ecol. Eng., 2009, 35, 159-174.

34. Metcalf and Eddy Inc., Wastewater Engineering: Treatment, Disposal and Reuse (eds Tchobanoglous, G. and Burton, F. L.), McGraw-Hill, New York, 1991, 3rd edn.

35. Reddy, K. R. and Patrick, W. H., Nitrogen transformations and loss in flooded soils and sediments. CRC Crit. Rev. Environ. Control., 1984, 13, 273-309.

36. Kadlec, R. H. and Knight, R. L., Treatment Wetlands, Lewis Publishers, Boca Raton, USA, 1996.

37. Paul, E. A. and Clark, F. E., Soil Microbiology and Biochemistry, Academic Press, San Diego, California, 1996.

38. Dunne, E. J. and Reddy, K. R., Phosphorus biogeochemistry of wetlands in agricultural watersheds. In Nutrient Management in Agricultural Watersheds: A Wetlands Solution (eds Dunne, E. J., Reddy, K. R. and Carton, O. T.), Academic Publishers, Wageningen, 2005, pp. 105-119.

ACKNOWLEDGEMENTS. We acknowledge the funding provided by USAID (University of Florida, Gainesville) and the Water4crops project. We acknowledge Dr Ramesh Reddy for the valuable thoughts and suggestions in this CW project. We thank and appreciate the efforts of research associates (Ms Sridivya, Ms Deepthi, Mr Hariom, Dr Manoj and Ms Radhika) for conducting the wastewater analysis in the ICRISAT laboratory. We also acknowledge the services of ICRISAT soil and plant laboratory (Mr Chenna Vijayaranganatha and Mrs Chetana Nimje).

doi: $10.18520 / \mathrm{cs} / \mathrm{v} 110 / \mathrm{i} 9 / 1764-1772$ 